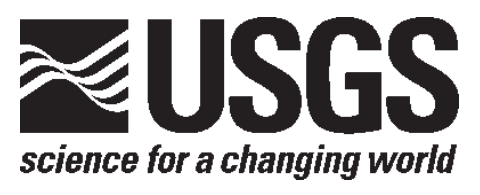

\title{
Physical Properties of Sidewall Cores from Decatur, Illinois
}

By C.A. Morrow, J.O. Kaven, D.E. Moore, and D.A. Lockner

Open-File Report 2017-1094

U.S. Department of the Interior

U.S. Geological Survey 


\section{U.S. Department of the Interior}

RYAN K. ZINKE, Secretary

\section{U.S. Geological Survey \\ William H. Werkheiser, Acting Director}

U.S. Geological Survey, Reston, Virginia: 2017

For more information on the USGS—-the Federal source for science about the Earth, its natural and living resources, natural hazards, and the environment-visit https://www.usgs.gov/ or call 1-888-ASK-USGS (1-888-275-8747).

For an overview of USGS information products, including maps, imagery, and publications, visit https://store.usgs.gov.

Any use of trade, firm, or product names is for descriptive purposes only and does not imply endorsement by the U.S. Government.

Although this information product, for the most part, is in the public domain, it also may contain copyrighted materials as noted in the text. Permission to reproduce copyrighted items must be secured from the copyright owner.

Suggested citation:

Morrow, C.A., Kaven, J.O., Moore, D.E., and Lockner, D.A., 2017, Physical properties of sidewall cores from Decatur, Illinois: U.S. Geological Survey Open-File Report 2017-1094, 21 p.,

https://doi.org/10.3133/ofr20171094.

ISSN 2331-1258 (online) 


\section{Contents}

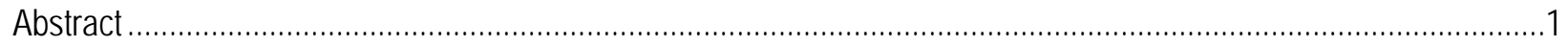

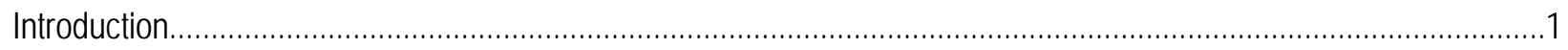

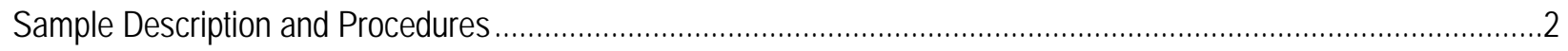

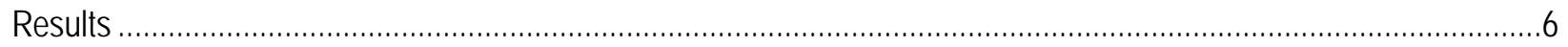

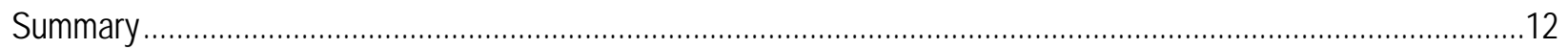

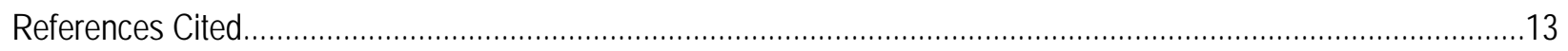

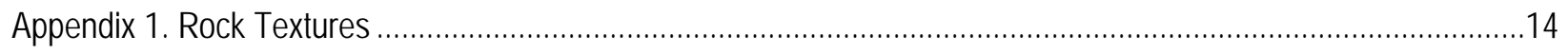

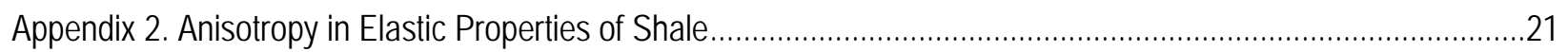

Figures

Figure 1. Map and cross-sectional view of Decatur, Illinois, carbon capture and sequestration (CSS) site.......... 3

Figure 2. Bulk density in grams per cubic centimeter versus depth graph of Decatur, Ill., sidewall cores. .......... 7

Figure 3. Porosity versus depth graph for Decatur, III., sidewall cores. ............................................... 8

Figure 4. Permeability at the estimated in situ confining pressure versus depth for Decatur, III., sidewall cores... 8

Figure 5. Graph of differential stress versus axial displacement for a Decatur, Ill., basement rock ................... 9

Figure 6. Graph of average Young's Modulus function of depth for Decatur, III., sidewall cores ...................... 10

Figure 7. Graph of Young's Modulus with depth for Decatur, III., sandstone reservoir rocks.......................... 10

Figure 8. Graph of Poisson's ratio as a function of depth for Decatur, III., sidewall cores.............................. 11

Figure 9. Graph of Poisson's ratio with depth for Decatur, III., sandstone reservoir rocks............................. 12

Figure A1. Photomicrographs of Eau Claire Shale cap rock (from a depth of $1,663.2 \mathrm{~m}$ ).............................. 14

Figure A2. Photomicrographs of Mount Simon Sandstone subunit D (from a depth of 1,810.0 m).................. 15

Figure A3. Photomicrograph of Mount Simon Sandstone subunit C (1,947.1 m) viewed with crossed

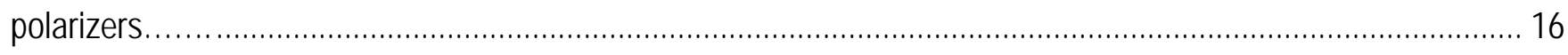

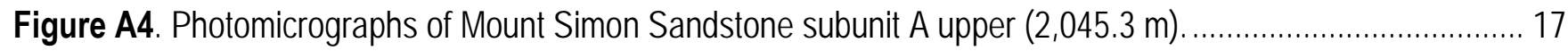


Figure A5. Photomicrograph of Mount Simon Sandstone subunit A upper viewed with plane-polarized

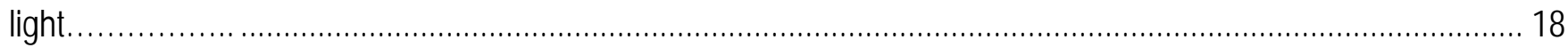

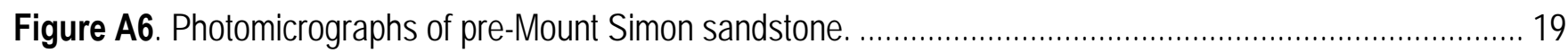

Figure A7. Photomicrographs of Precambrian basement rocks from depths of 2,187.2 $\mathrm{m}(A)$ and $2188.2 \mathrm{~m}(B)$,

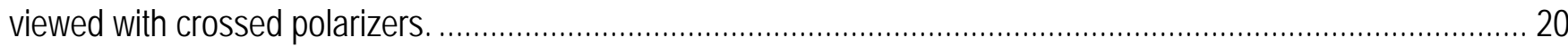

\section{Tables}

Table 1. Physical properties of Decatur, III., sidewall core samples ............................................................ 5 


\section{Abbreviations}

ADM

Archer Daniels Midland

CCS

carbon capture and sequestration

IBDP

Illinois Basin Decatur Project

ICCS Illinois Industrial Carbon Capture and Sequestration project

ISGS Illinois State Geological Survey

SCS Schlumberger Carbon Services

USGS U.S. Geological Survey

VW

verification well 


\title{
Physical Properties of Sidewall Cores from Decatur, Illinois
}

By C.A. Morrow, J.O. Kaven, D.E. Moore, and D.A. Lockner

\begin{abstract}
To better assess the reservoir conditions influencing the induced seismicity hazard near a carbon dioxide sequestration demonstration site in Decatur, Ill., core samples from three deep drill holes were tested to determine a suite of physical properties including bulk density, porosity, permeability, Young's modulus, Poisson's ratio, and failure strength. Representative samples of the shale cap rock, the sandstone reservoir, and the Precambrian basement were selected for comparison. Physical properties were strongly dependent on lithology. Bulk density was inversely related to porosity, with the cap rock and basement samples being both least porous ( $<3$ percent) and densest ( $\sim 2.6$ grams per cubic centimeter [g/cc]). Permeability was highest in the reservoir sandstones $\left(10^{-15}\right.$ to $10^{-18}$ meters squared $\left.\left[\mathrm{m}^{2}\right]\right)$ relative to the cap rock and basement rocks $\left(<10^{-21} \mathrm{~m}^{2}\right)$. Young's modulus was distinctly higher in the basement rocks $(45$ to 80 gigapascal [GPa]) compared to the cap rock and sandstones (19 to $57 \mathrm{GPa}$ ). Poisson's ratio for the sandstones varied widely ( 0.14 to 0.27 ), but the highest values were similar to the cap rock and basement rocks $(0.24$ to 0.28$)$. These physical properties reflect the layered structure of the reservoir and adjacent rocks at the Decatur site. However, within the sandstone there is a great deal of lithologic variety, accounting for the large range in physical parameters for this geologic unit.
\end{abstract}

\section{Introduction}

In recent years, the United States has expanded the use of technologies that involve injection (and in some cases associated production) of fluid at depth to meet future energy needs, limit emissions of greenhouse gases, and safely dispose of wastewater. To varying degrees, the injection and production practices employed in these technologies have the potential to introduce seismic hazards (National Research Council, 2012). The significance of induced seismicity associated with wastewater disposal from natural gas production is highlighted by the 2008 magnitude $(M) 3.3$ and 2009 earthquake sequence near the Dallas-Fort Worth Airport (Frohlich and others, 2011), and the 2011 seismicity induced by the deep injection of wastewater near Guy, Ark. (M 4.7) and Youngstown, Ohio (M 4.0; Horton, 2012; Kim, 2013). Likewise, there is a potential seismic hazard associated with geologic carbon capture and sequestration (CCS) projects, which involve injection of vast quantities of supercritical carbon dioxide $\left(\mathrm{CO}_{2}\right)$ into sedimentary basins located in or near major urban centers of the eastern and central United States (National Research Council, 2012).

The U.S. Geological Survey (USGS) operates a seismic network to assess the seismic hazard associated with CCS in Decatur, Ill., where Archer Daniels Midland (ADM) operates a corn-ethanol 
fermentation facility that generates $\mathrm{CO}_{2}$ as a byproduct. Decatur is the site for two CCS projects, one past, one present:

- The Illinois Basin Decatur Project (IBDP), led by the Illinois State Geological Survey (ISGS), which injected supercritical $\mathrm{CO}_{2}$ from November 2011 until November 2014 (Finley, 2014)

- The Illinois Industrial Carbon Capture and Sequestration project (ICCS), led by ADM, which started injecting supercritical $\mathrm{CO}_{2}$ in April 2017 (Gollakota and McDonald, 2014).

In both projects large quantities of supercritical $\mathrm{CO}_{2}$ are injected into the lower Mount Simon Sandstone, a basal brine reservoir in the Illinois Basin. The IBDP injected 1,000 metric tons/day of $\mathrm{CO}_{2}$ into the lower Mount Simon Sandstone at a depth of 2.1 kilometers (km), from November 2011 to November 2014. Only low magnitude, $<M$ 1.2, microseismicity was detected (Kaven and others, 2015) and fluid pressure was not significantly altered outside of the injection horizon during the first phase (Strandli and others, 2014). The ICCS will inject supercritical $\mathrm{CO}_{2}$ into a new well (CCS\#2) about $1 \mathrm{~km}$ north of the IBDP well, at a rate of 3,000 tons/day (1.1 million tons/year) over a five-year period. The CCS demonstration site is an excellent natural laboratory for better understanding the seismic hazards that may be associated with geologic $\mathrm{CO}_{2}$ sequestration.

To improve our understanding of the conditions and material properties at the Decatur CCS site, we carried out rock testing on sidewall and whole cores obtained by the ISGS and Schlumberger Carbon Services (SCS) from CCS\#2 and nearby verification well (VW) drill holes. This report summarizes the findings from our testing.

\section{Sample Description and Procedures}

Fifteen samples were obtained for analysis from three drill holes at the Decatur, Ill., wastewater injection site; VW1, VW2, and the injection well CCS\#2 (fig. 1). VW1 and VW2 are located about 1,350 meters (m) apart, and CCS\#2 is $525 \mathrm{~m}$ from VW1 and $800 \mathrm{~m}$ from VW2. Because the stratigraphic column is essentially the same in each well and ground surface elevation is uniform across the site, depths from one well can be directly correlated with depths in an adjacent well. The samples are:

- $\quad$ Eau Claire Shale cap rock from VW1 at a depth of 1,663.2 m

- Mount Simon Sandstone subunit D—sidewall core from VW1 at a depth of 1,810.0 m

- Mount Simon Sandstone subunit A-upper sidewall cores from VW1 at depths of 2,045.3, 2,059.2, 2,079.7 and 2,100.0 m

- Mount Simon Sandstone subunit C-sidewall core from VW2 at a depth of 1,947.1 m

- Pre-Mount Simon sandstone-sidewall cores from VW2 at depths of 2,144.9 and 2,155.5 m

- Six sidewall cores from the Precambrian basement rock in injection well CCS\#2, between 2,184.8 and 2,188.2 $\mathrm{m}$ depth.

The Eau Claire Shale is fragile and could not be cored into cylindrical experimental samples. The sample was cut into cubes 2.54 centimeters $(\mathrm{cm})$ on a side for testing in both vertical and horizontal orientations. The Mount Simon Sandstone and Precambrian basement sidewall cores, between 2.28 and $2.54 \mathrm{~cm}$ in diameter, were more competent, requiring only that the ends be ground to make them flat and parallel. As a result, all of these samples were different lengths, varying between 2.1 and $6.6 \mathrm{~cm}$. 

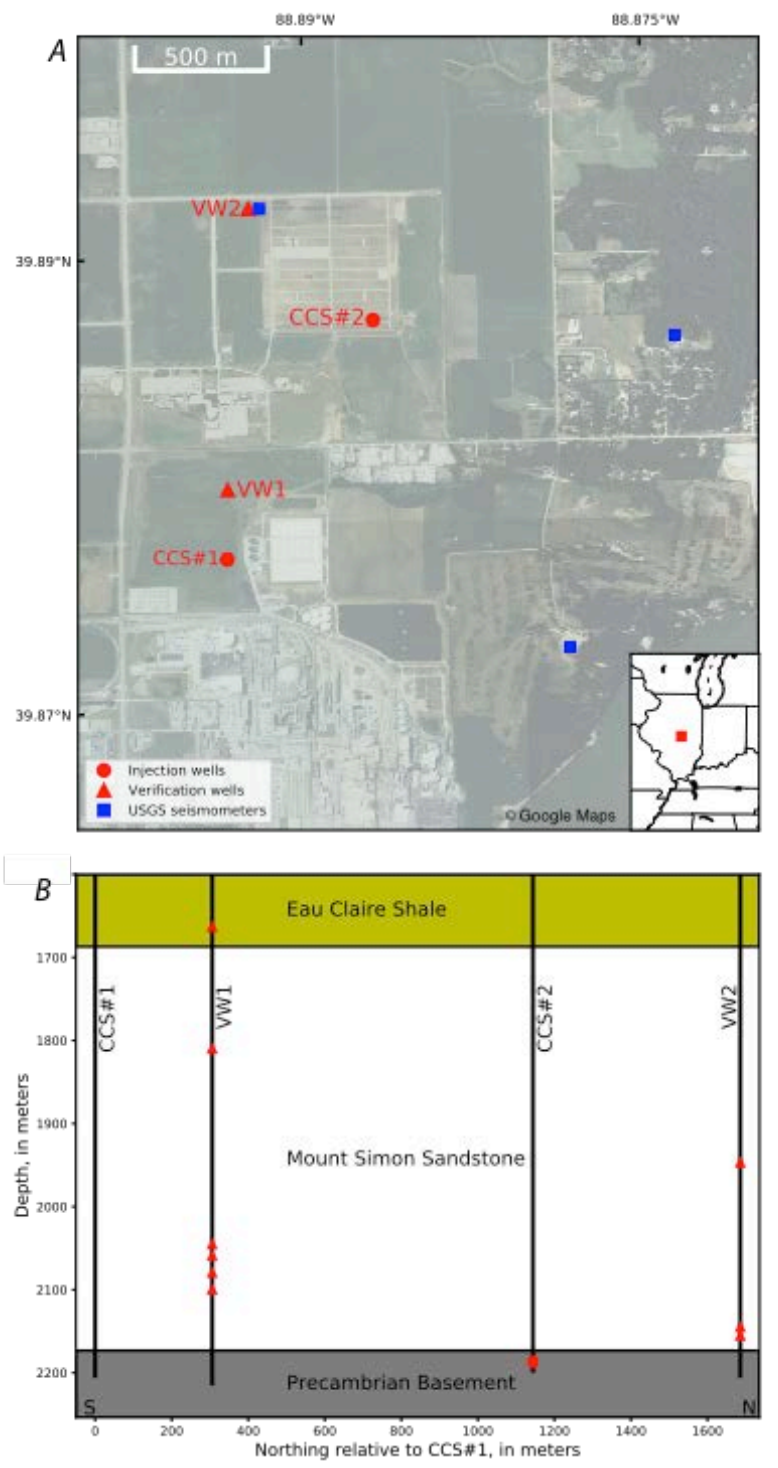

Figure 1. Map and cross-sectional view of Decatur, Illinois, carbon capture and sequestration (CSS) site. A, Map of Decatur, III., area showing locations of injection wells, verification wells, and seismometers at the CSS site. $B$, Cross-sectional view (to the west) of core sample depths (red dots). Note that the geologic unit depths are approximate. 


\section{Porosity}

All samples were dried in a vacuum oven overnight at $80{ }^{\circ} \mathrm{C}$ and then weighed to determine bulk density (table 1). The samples were then saturated in a vacuum oven and the wet weight determined while suspended in water. Porosity, $\Phi$, was calculated using the relation

$\Phi=1-\left[\left(\mathrm{W}_{\mathrm{d}}-\mathrm{W}_{\mathrm{w}}\right) / \mathrm{V}\right]$,

where $W_{d}$ is dry weight, $W_{w}$ is submerged wet weight, and $V$ is sample volume.

\section{Permeability}

For permeability measurements, samples were jacketed in latex tubing, which was clamped to endplugs to isolate the sample from the silicone-oil confining fluid. A stainless-steel mesh placed on either end of the sample enabled uniform flow into and out of the core. This assembly was then placed inside a pressure vessel and connected to a pore-pressure system comprised of a pressure generator and transducer. The sample and pore-pressure assembly were evacuated for as much as one hour through the pore-pressure lines and then saturated with deionized water. However, for shale samples, $0.01 \mathrm{molar} \mathrm{NaCl}$ was used to help stabilize the clay constituents, because deionized water would cause the clays to swell. A representative effective pressure $\left(\mathrm{P}_{\mathrm{e}}=\right.$ confining pressure - pore pressure $)$ was assigned to each sample based on sample depth, assuming an average overburden density of $2.3 \mathrm{~g} / \mathrm{cc}$ and a hydrostatic porepressure gradient. Then, permeability was measured for each sample at its representative effective pressure (table 1). Permeability was measured using a steady-state flow technique. Pore pressure on the inlet side of the sample was held at a fixed value; 1 megapascal (MPa) for the sandstones and as much as 5 MPa for the tight shale and Precambrian basement samples. The outlet was vented to the atmosphere and confining pressure was set to provide the desired effective pressure. Flow rate was determined by recording the change in volume of the pore-pressure pump needed to maintain the applied pressure gradient. Permeability was determined using Darcy's Law:

$(\mathrm{Q} / \mathrm{A})=(\mathrm{k} / \mu)(\mathrm{dP} / \mathrm{dx})$,

where $\mathrm{Q}$ is flow rate, $\mathrm{A}$ is the cross-sectional area of the sample, $\mathrm{k}$ is permeability, $\mu$ is the dynamic viscosity of water ( 0.95 centipoise in these experiments), and $\mathrm{dP} / \mathrm{dx}$ is the pore pressure gradient across the length of the sample. Permeability values are accurate to roughly \pm 20 percent below $10^{-21} \mathrm{~m}^{2}$ and \pm 10 percent above $10^{-21} \mathrm{~m}^{2}$.

\section{Young's Modulus, Poisson's Ratio and Fracture Strength}

With the exception of the fragile shale, samples were reused to measure elastic properties. For these experiments, axial and transverse strain gauges were glued to the side of each sample. The cores were then jacketed in three layers of polyolefin shrink tubing and clamped to the endplug. This jacketing procedure was used to accommodate the strain gauge wires, which led from the gauges out into the confining fluid and then to high-pressure feed-through ports, where the signals were brought out of the pressure vessel. Before the start of each test, the strain gauges were calibrated and zeroed. An axial stress $\left(\sigma_{1}\right)$ was applied by a piston that advanced at 1 micrometer/second $(\mu \mathrm{m} / \mathrm{sec})$ until each sample had 
reached approximately half of its failure strength (sometimes referred to as peak or ultimate strength), either estimated or measured (table 1). The axial stress was cycled to distinguish between elastic and inelastic strain. The elastic strain response was used to determine Young's modulus, $\mathrm{E}_{\mathrm{y}}$, by the relation

$\mathrm{E}_{\mathrm{y}}=\sigma_{1} / \varepsilon_{\mathrm{ax}}$

where $\varepsilon_{a x}$ is axial strain.

Poisson's ratio, $v$, is defined as

$\nu=-\varepsilon_{\mathrm{tr}} / \varepsilon_{\mathrm{ax}}$

where $\varepsilon_{\text {tr }}$ is transverse strain.

Anisotropy in the shale owing to bedding results in two independent values for Young's modulus and Poisson's ratio (one parallel to bedding and the other perpendicular to bedding). Young's modulus was measured both parallel and perpendicular to bedding, but Poisson's ratio was only measured perpendicular to bedding. Details are provided in appendix 2. In addition to the elastic measurements, the shales and three of the Precambrian basement rocks were loaded to failure. The reservoir rocks were restricted to non-destructive testing.

Table 1. Physical properties of Decatur, III., sidewall core samples

\begin{tabular}{|c|c|c|c|c|c|c|c|c|}
\hline $\begin{array}{c}\text { Sample } \\
\text { Depth } \\
\text { (meters) }\end{array}$ & Well & $\begin{array}{c}\mathrm{Pe}_{\mathrm{e}} \\
(\mathrm{MPa})\end{array}$ & $\begin{array}{l}\text { Density } \\
\text { (g/cc) }\end{array}$ & $\begin{array}{l}\text { Porosity } \\
(\Phi)\end{array}$ & $\begin{array}{l}\text { Permeability } \\
\qquad\left(\mathrm{m}^{2}\right)\end{array}$ & $\begin{array}{c}\text { Young's } \\
\text { Modulus } \\
\text { (GPa) }\end{array}$ & $\begin{array}{c}\text { Poisson's } \\
\text { ratio } \\
(v) \\
\end{array}$ & $\begin{array}{c}\text { Failure } \\
(\mathrm{MPa})\end{array}$ \\
\hline \multicolumn{9}{|c|}{ Eau Claire Shale } \\
\hline $1,663.2 \mathrm{~A}$ & VW1 & 21.6 & 2.584 & 0.029 & $8.93 e-22$ & 32.7 & 0.255 & 205.2 \\
\hline 1,663.2 B & VW1 & 21.6 & 2.584 & 0.029 & $3.87 e-22$ & 36.5 & 0.287 & 204.6 \\
\hline \multicolumn{9}{|c|}{ Sandstone units } \\
\hline $1,810.0$ & VW1 & 23.5 & 2.495 & 0.062 & $9.12 \mathrm{e}-19$ & 57.3 & 0.137 & \\
\hline $1,947.1$ & VW2 & 25.3 & 2.427 & 0.087 & $9.68 \mathrm{e}-18$ & 54.0 & 0.179 & \\
\hline $2,045.3$ & VW1 & 26.6 & 2.081 & 0.214 & $3.24 \mathrm{e}-17$ & 20.6 & 0.232 & \\
\hline $2,059.2$ & VW1 & 26.8 & 2.093 & 0.211 & $1.50 \mathrm{e}-17$ & 19.0 & 0.268 & \\
\hline $2,079.7$ & VW1 & 27.0 & 2.290 & 0.134 & $1.83 \mathrm{e}-15$ & 41.0 & & \\
\hline $2,100.0$ & VW1 & 27.3 & 2.243 & 0.152 & $2.72 \mathrm{e}-17$ & 25.1 & 0.272 & \\
\hline $2,144.9$ & VW2 & 27.9 & 2.381 & 0.107 & $1.17 \mathrm{e}-18$ & 36.9 & 0.138 & \\
\hline $2,155.5$ & VW2 & 28.0 & 2.280 & 0.146 & $4.71 \mathrm{e}-18$ & 29.9 & 0.191 & \\
\hline
\end{tabular}




\begin{tabular}{ccccccccc}
$\begin{array}{c}\text { Sample } \\
\text { Depth } \\
\text { (meters) }\end{array}$ & Well & $\begin{array}{c}\mathrm{Pe}_{\mathrm{e}} \\
(\mathrm{MPa})\end{array}$ & $\begin{array}{c}\text { Density } \\
(\mathbf{g} / \mathrm{cc})\end{array}$ & $\begin{array}{c}\text { Porosity } \\
(\boldsymbol{\Phi})\end{array}$ & $\begin{array}{c}\text { Permeability } \\
\left(\mathrm{m}^{2}\right)\end{array}$ & $\begin{array}{c}\text { Young's } \\
\text { Modulus } \\
(\mathrm{GPa})\end{array}$ & $\begin{array}{c}\text { Poisson's } \\
\text { ratio } \\
(\mathrm{v})\end{array}$ & $\begin{array}{c}\text { Failure } \\
(\mathrm{MPa})\end{array}$ \\
\hline & & & \multicolumn{2}{c}{ Precambrian basement rock } \\
$2,184.8$ & $\mathrm{CCS} 2$ & 28.4 & 2.656 & 0.009 & $1.71 \mathrm{e}-21$ & 45.7 & 0.236 & 286.9 \\
$2,186.0$ & $\mathrm{CCS} 2$ & 28.4 & 2.657 & 0.009 & $6.67 \mathrm{e}-23$ & 69.0 & 0.246 & \\
$2,186.9$ & $\mathrm{CCS} 2$ & 28.4 & 2.700 & 0.000 & $4.33 \mathrm{e}-23$ & 74.1 & 0.237 & 407.6 \\
$2,187.2$ & $\mathrm{CCS} 2$ & 28.4 & 2.691 & 0.006 & $8.84 \mathrm{e}-23$ & 80.7 & 0.261 & 585.1 \\
$2,188.2$ & $\mathrm{CCS} 2$ & 28.4 & 2.672 & 0.010 & & 70.7 & 0.276 & \\
$2,188.5$ & $\mathrm{CCS} 2$ & 28.4 & 2.677 & 0.008 & $8.62 \mathrm{e}-23$ & 76.0 & 0.240 & \\
\hline
\end{tabular}

Shale cores: A, bedding-perpendicular core orientation; B, bedding-parallel core orientation; all other cores are bedding-perpendicular orientation.

$\mathrm{P}_{\mathrm{e}}$ is estimated in situ effective pressure based on depth, hydrostatic pore fluid pressure, and an average core density of $2.3 \mathrm{~g} / \mathrm{cc}$.

$\Phi$ values computed using equation 1.

Both determinations of Poisson's ratio for the Eau Claire Shale are for v' ( $v$ was not measured; see appendix 2 for details).

Failure stress is peak differential stress $\left(\sigma_{\Delta}=\sigma_{1}-\mathrm{P}_{\mathrm{e}}\right)$ at failure.

GPa, gigapascal; MPa, megapascal; m, meters; $\mathrm{m}^{2}$, meters squared; g/cc, grams per cubic centimeter.

\section{Results}

Sample bulk density is shown in figure 2 as a function of depth. Density correlates with lithology; the Precambrian basement rocks are the densest (2.6-2.7 g/cc), the sandstone reservoir rocks are the least dense (2.2-2.5 g/cc), and the Eau Claire Shale is intermediate at $2.6 \mathrm{~g} / \mathrm{cc}$. Porosity, $\Phi$, also correlates with lithology, as seen in figure 3. The Precambrian basement rocks all have a porosity of less than one percent. Reservoir sandstones, which vary greatly in outward appearance, have porosities ranging from 6 to 21 percent, and the shale porosity is 3 percent. This wide range in porosity has a strong influence on permeability, shown as a function of depth in figure 4, as the low porosity shale and basement rocks have exceptionally low permeability values $\left(<10^{-21} \mathrm{~m}^{2}\right)$. Reservoir sandstones cover a wide range of permeabilities from $10^{-15}$ to $10^{-19} \mathrm{~m}^{2}$. The core at 2,079.7 $\mathrm{m}$ has a particularly high permeability relative to porosity (see table 1). Photomicrographs of samples from each of the tested rock units, presented in appendix 1, illustrate some of the factors that influence porosity and permeability. These factors include the presence or absence of authigenic clays in pore spaces in the sandstones, which substantially reduce porosity and permeability; silica overgrowths on quartz grains that fill pore space; and recrystallization of the quartzofeldspathic groundmass into an interlocking texture in the Precambrian basement rocks that reduces porosity and permeability. It should be noted that in sandstone samples where the pore space is lined with expandable clay, pore-fluid chemistry also plays a role in permeability measurements because of the differing degrees to which clay layers swell with brine concentration. Because we tested sandstone 
samples with deionized water, we would expect lower permeability results for samples with a significant expandable-clay fraction when compared to tests using, for example, brine or gas as a pore fluid. However, a number of the sandstone samples tested (figs. A2, A3, and A5) had little or no clay filling and should provide permeability values comparable to in-situ permeability.

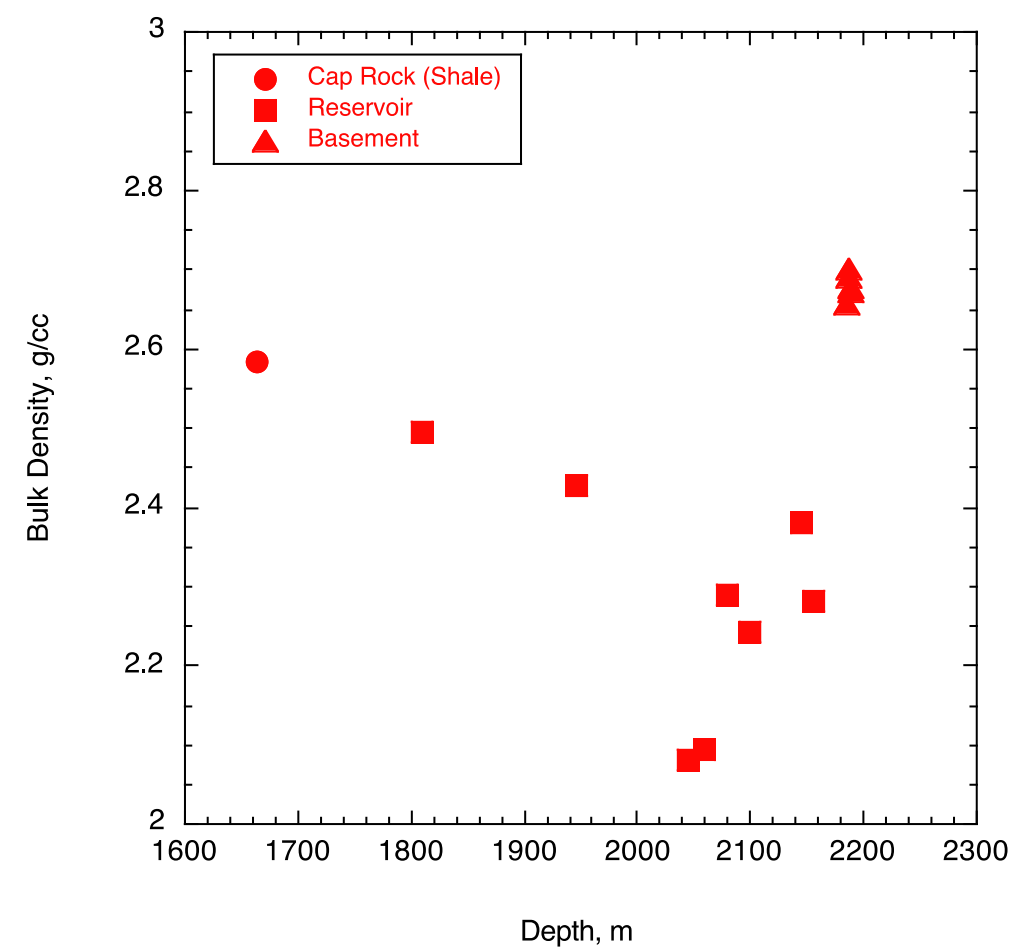

Figure 2. Bulk density in grams per cubic centimeter versus depth graph of Decatur, III., sidewall cores. 


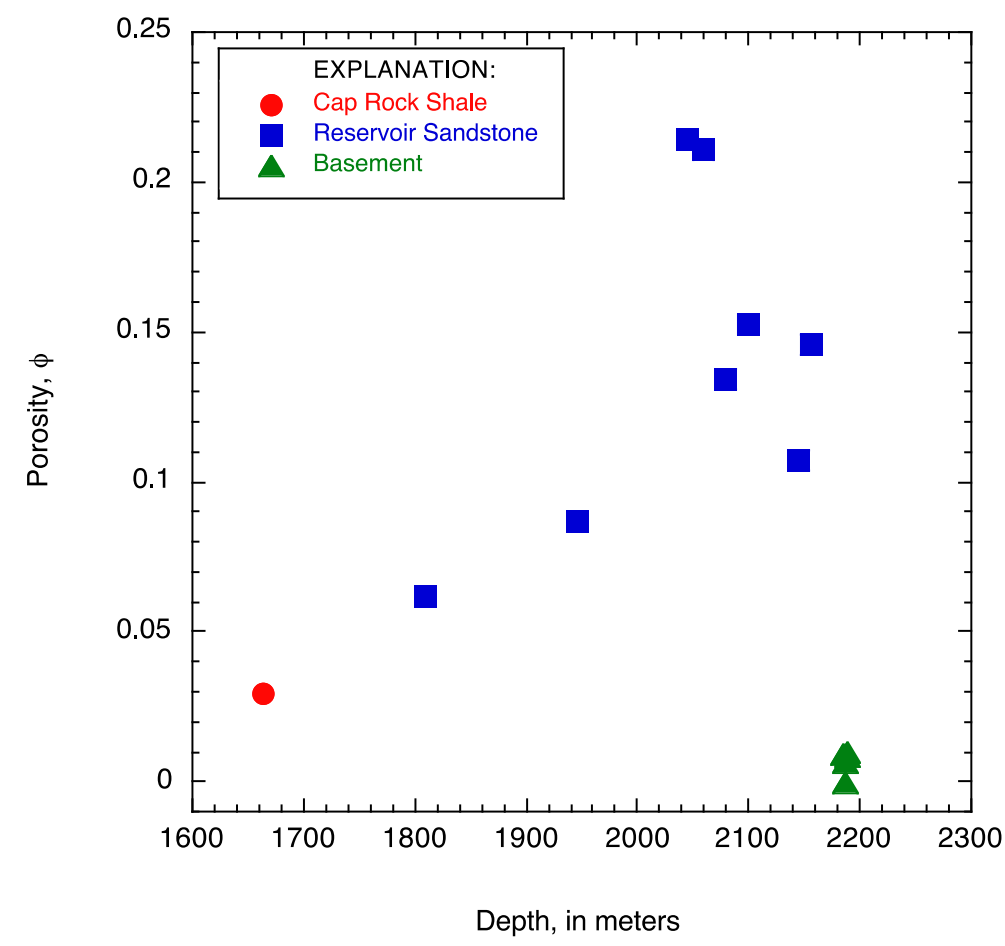

Figure 3. Porosity versus depth graph for Decatur, III., sidewall cores.

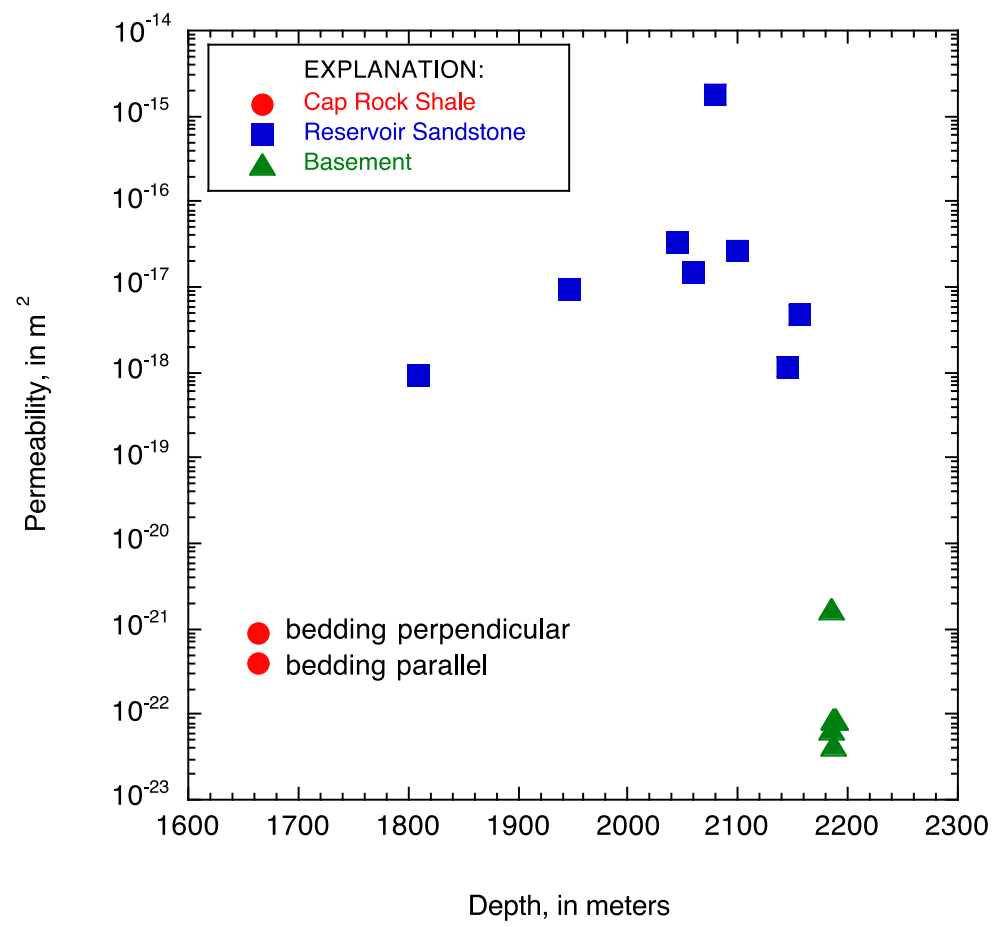

Figure 4. Permeability in meters squared at the estimated in situ confining pressure versus depth for Decatur, III., sidewall cores. 
A typical stress-displacement curve is shown in figure 5 for a Precambrian basement rock from a depth of 2,184.8 $\mathrm{m}$ that was stress-cycled twice to progressively higher pressures and then loaded to failure. Differential stress (axial load minus confining pressure) is shown for loading only, the unloading curves have been removed for clarity. In this example, when the axial load is removed and re-applied, there is a permanent offset in the stress-displacement curve that represents non-recoverable inelastic strain. The second loading cycle then provides a good measure of elastic strain until the previous cycle-peak load is exceeded. Above this stress, additional inelastic strain is again accumulated, resulting in an additional offset of the loading curve when stress cycling is repeated. Elastic moduli were determined from the last cycle, at pressures not exceeding the peak load of the previous cycle, to exclude non-recoverable inelastic strain.

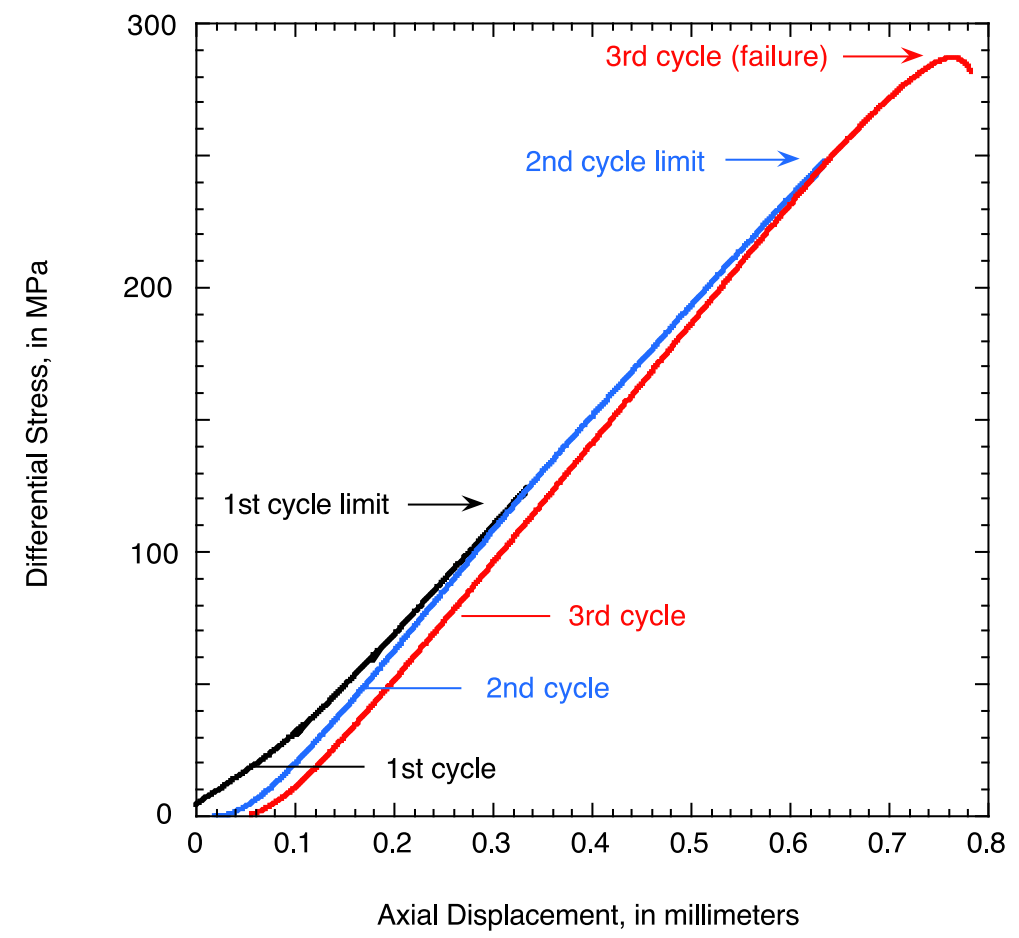

Figure 5. Graph of differential stress in megapascals versus axial displacement (loading curves only) for a Decatur, III., Precambrian basement rock from a 2,184.8-m depth.

Average Young's modulus as a function of depth for all samples is shown in figure 6. Values range from 19 to 80 gigapascal (GPa) (table 1). Higher Young's modulus generally correlates with lower porosity. Thus, the low-permeability basement rocks are also the stiffest. For the Eau Claire Shale, Young's modulus showed a 10 percent anisotropy with higher stiffness parallel to bedding.

Young's modulus varies slightly with applied differential stress. Figure 7 shows Young's Modulus for the reservoir rocks only, with data from figure 6 broken down into four progressively higher differential stress ranges as the sample was loaded. With the exception of the shallowest sandstone, this plot demonstrates that Young's modulus generally increases 20-30 percent with increasing differential stress between the lowest $(0-20 \mathrm{MPa})$ and highest $(60-80 \mathrm{MPa})$ pressure range. 


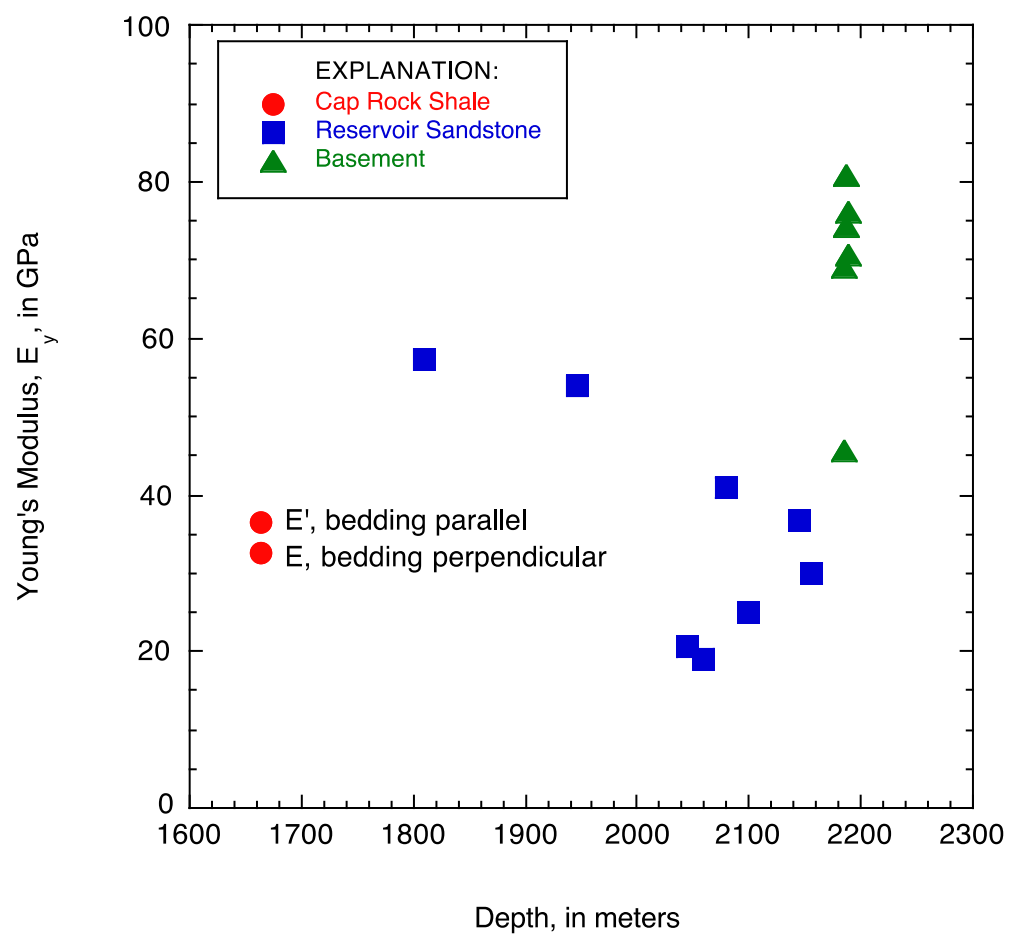

Figure 6. Graph of average Young's Modulus in gigapascals as a function of depth for Decatur, III., sidewall cores.

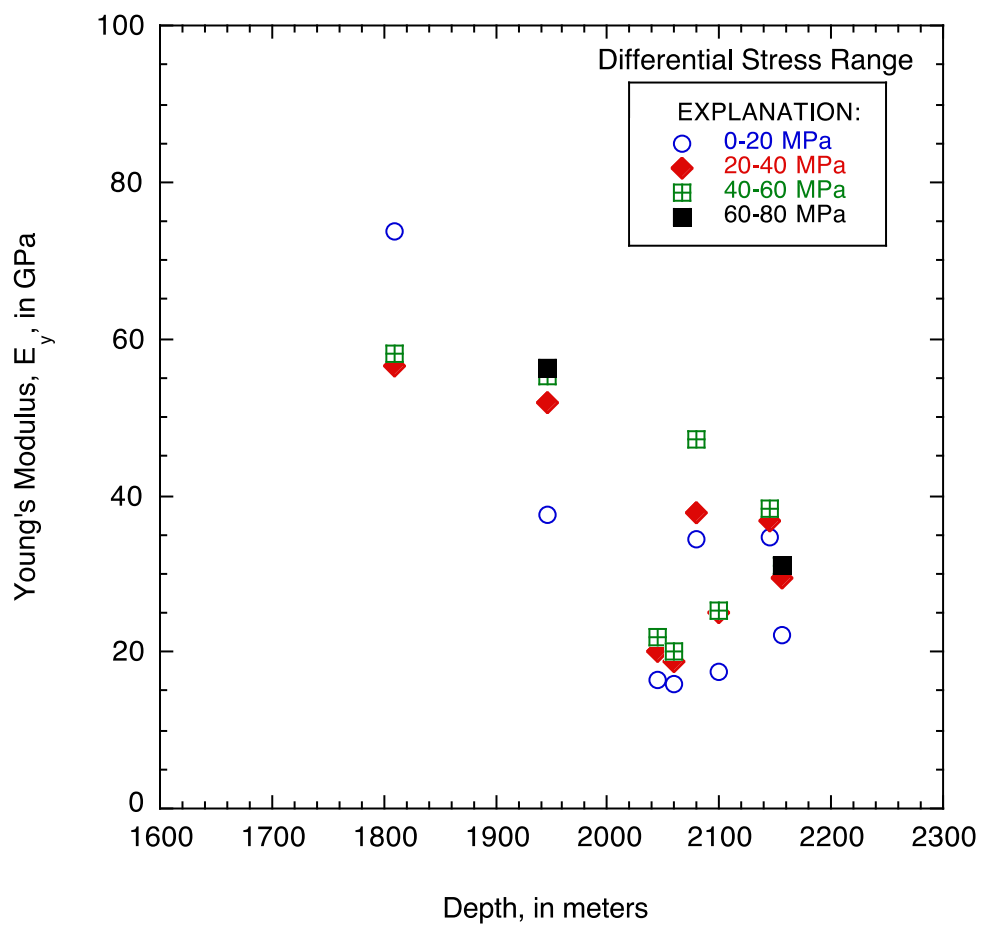

Figure 7. Graph of Young's Modulus in gigapascals with depth for Decatur, III., sandstone reservoir rocks. Data from figure 6 has been divided into four differential stress ranges, showing variations in Young's Modulus as the sample was loaded. 
The average Poisson's ratio, also taken from the last stress cycle of each sample, is shown in figure 8. Values range from 0.13 to 0.29 , with the most variation occurring in the reservoir sandstones. Poisson's ratio is also dependent on differential stress, as shown in figure 9. These data (reservoir rocks only) were averaged over $20 \mathrm{MPa}$ intervals in the same way as the Young's modulus data in figure 7. Poisson's ratio increases with differential stress by 20-70 percent over the pressure ranges shown here.

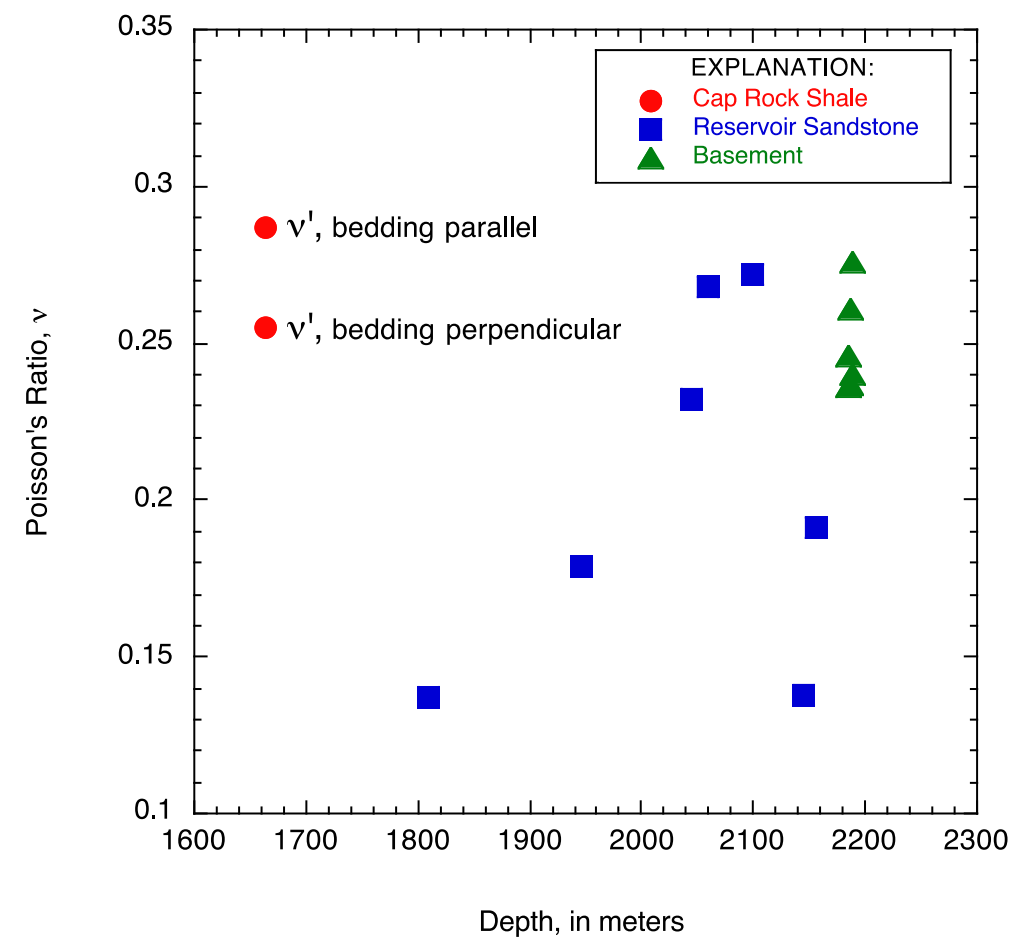

Figure 8. Graph of Poisson's ratio as a function of depth for Decatur, III., sidewall cores. See appendix 2 for a discussion of $v^{\prime}$ for the cap rock. 


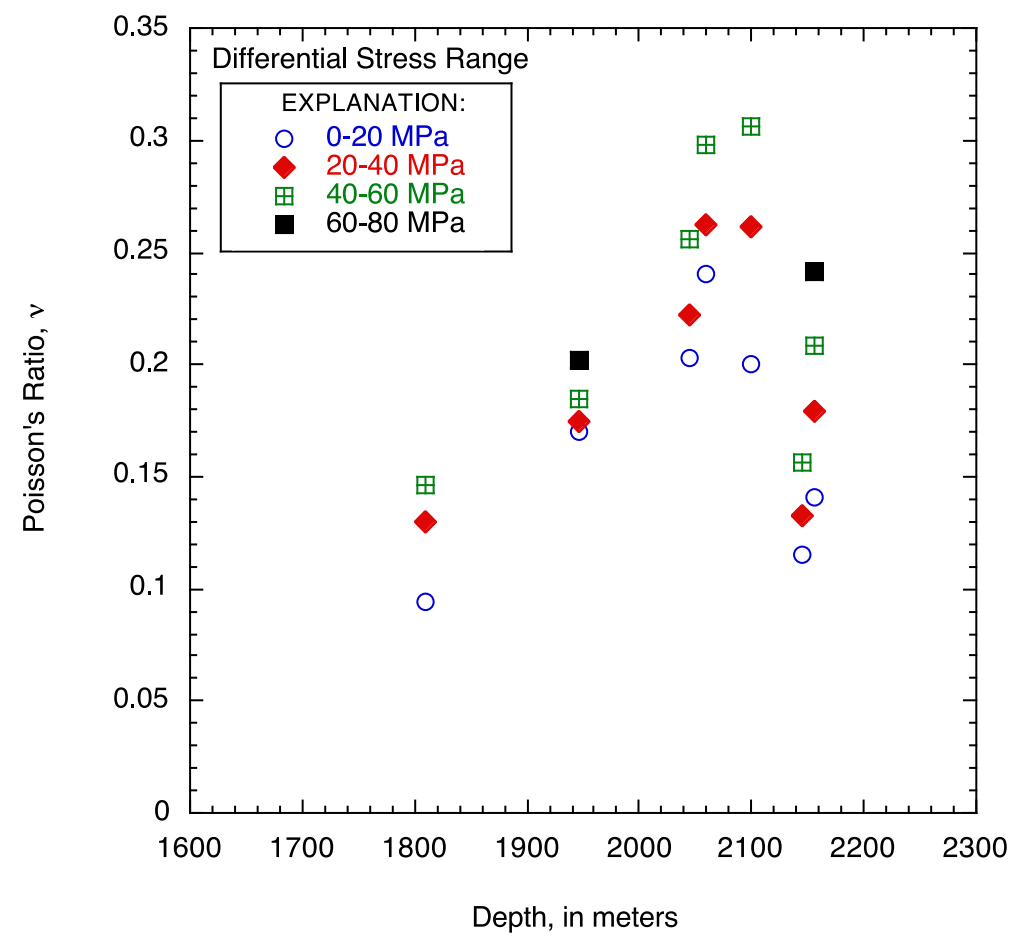

Figure 9. Graph of Poisson's ratio with depth for Decatur, III., sandstone reservoir rocks. Data from figure 8 has been divided into four differential stress ranges, showing variations in Poisson's ratio as the sample was loaded.

The peak differential stress at failure for five samples is given in table 1 . Values for the shale samples perpendicular and parallel to bedding are nearly the same, at 205.2 and 204.6 MPa, respectively. Precambrian basement rocks failed at differential stresses between 286 and $585 \mathrm{MPa}$. This wide range may be due to preexisting internal flaws.

\section{Summary}

Density, porosity, permeability, and elastic moduli are strongly influenced by sample lithology. The Mount Simon Sandstones have bulk densities of 2.0 to $2.5 \mathrm{~g} / \mathrm{cc}$, porosities from 6 to 21 percent, permeability from $1.8 \times 10^{-15}$ to $9.1 \times 10^{-19} \mathrm{~m}^{2}$, Young's modulus from 19 to $57 \mathrm{GPa}$, and Poisson's ratio of 0.13 to 0.27 . The cap rock and Precambrian basement rocks are both low porosity and high density, with extremely low permeabilities and generally higher Young's modulus and Poisson's ratios. These physical properties reflect the layered structure of the reservoir and surrounding rocks at the Decatur site. However, the sandstones have a great deal of lithologic variety, accounting for some overlap in Young's modulus and Poisson's ratio values. 


\section{References Cited}

Deng, Shang, Cilona, Antonino, Morrow, Carolyn, Mapeli, Cesar, Liu, Chun, Lockner, David, Prasad, Manika, and Aydin, Attila, 2015, Cross-bedding related anisotropy and its interplay with various boundary conditions in the formulation and orientation of joints in an aeolian sandstone: Journal of Structural Geology, v. 77, p. 175-190, https://doi.org/10.1016/j.jsg.2015.05.005.

Finley, R.J., 2014, An overview of the Illinois Basin - Decatur Project: Greenhouse Gases-Science and Technology, v. 4, no. 5, p. 571-579, https://doi.org/10.1002/ghg.1433.

Frohlich, Cliff, Hayward, Chris, Stump, Brian, and Potter, Eric, 2011, The Dallas-Fort Worth earthquake sequence-October 2008 through May 2009: Bulletin of the Seismological Society of America, v. 101, no. 1, p. 327-340, https://doi.org/10.1785/0120100131.

Gollakota, Sai, and McDonald, Scott, 2014, Commercial-scale CCS project in Decatur, Illinois - Construction status and operational plans for demonstration: Energy Procedia, v. 63, p. 5986-5993, https://doi.org/10.1016/j.egypro.2014.11.633.

Horton, Steve, 2012, Disposal of hydrofracking waste fluid by injection into subsurface aquifers triggers earthquake swarm in central Arkansas with potential for damaging earthquake: Seismological Research Letters, v. 83, no. 2, p. 250-260, https://doi.org/10.1785/gssrl.83.2.250.

Kaven, J.O., Hickman, S.H., McGarr, A.F., and Ellsworth, W.E., 2015, Surface monitoring of microseismicity at the Decatur, Illinois, $\mathrm{CO}_{2}$ sequestration demonstration site: Seismological Research Letters, v. 86, no. 4, p. 1096-1101, https://doi.org/10.1785/0220150062.

Kim, W.-Y., 2013, Induced seismicity associated with fluid injection into a deep well in Youngstown, Ohio: Journal of Geophysical Research-Solid Earth, v. 118, no. 7, p. 3506-3518, https://doi.org/10.1002/jgrb.50247.

Lekhnitskii, S.G., 1963, Theory of elasticity of an anisotropic elastic body: San Francisco, Holden-Day, Inc., $404 \mathrm{p}$.

National Research Council, 2012, Induced Seismicity Potential in Energy Technologies: Washington, D.C., National Academies Press, 262 p, https://doi.org/10.17226/13355.

Strandli, C.W., Mehnert, E. and Benson, S.M., 2014, $\mathrm{CO}_{2}$ plume tracking and history matching using multilevel pressure monitoring at the Illinois Basin - Decatur Project: Energy Procedia, v. 63, p. 44734484. [Also available at https://doi.org/10.1016/j.egypro.2014.11.483.] 


\section{Appendix 1. Rock Textures}

Measured porosity and permeability values of the cap, reservoir, and basement rocks at the Decatur CCS site vary over wide ranges. Thin sections were prepared from eight of the tested samples for petrographic examination, to correlate rock textures and mineral assemblages with their physical properties, in particular porosity (fig. 3) and permeability (fig. 4). Several of these factors are illustrated in the photomicrographs of the Mount Simon Shale cap rock (fig. A1), the sandstone reservoir units (figs. A2A6), and the Precambrian basement rocks (fig. A7).
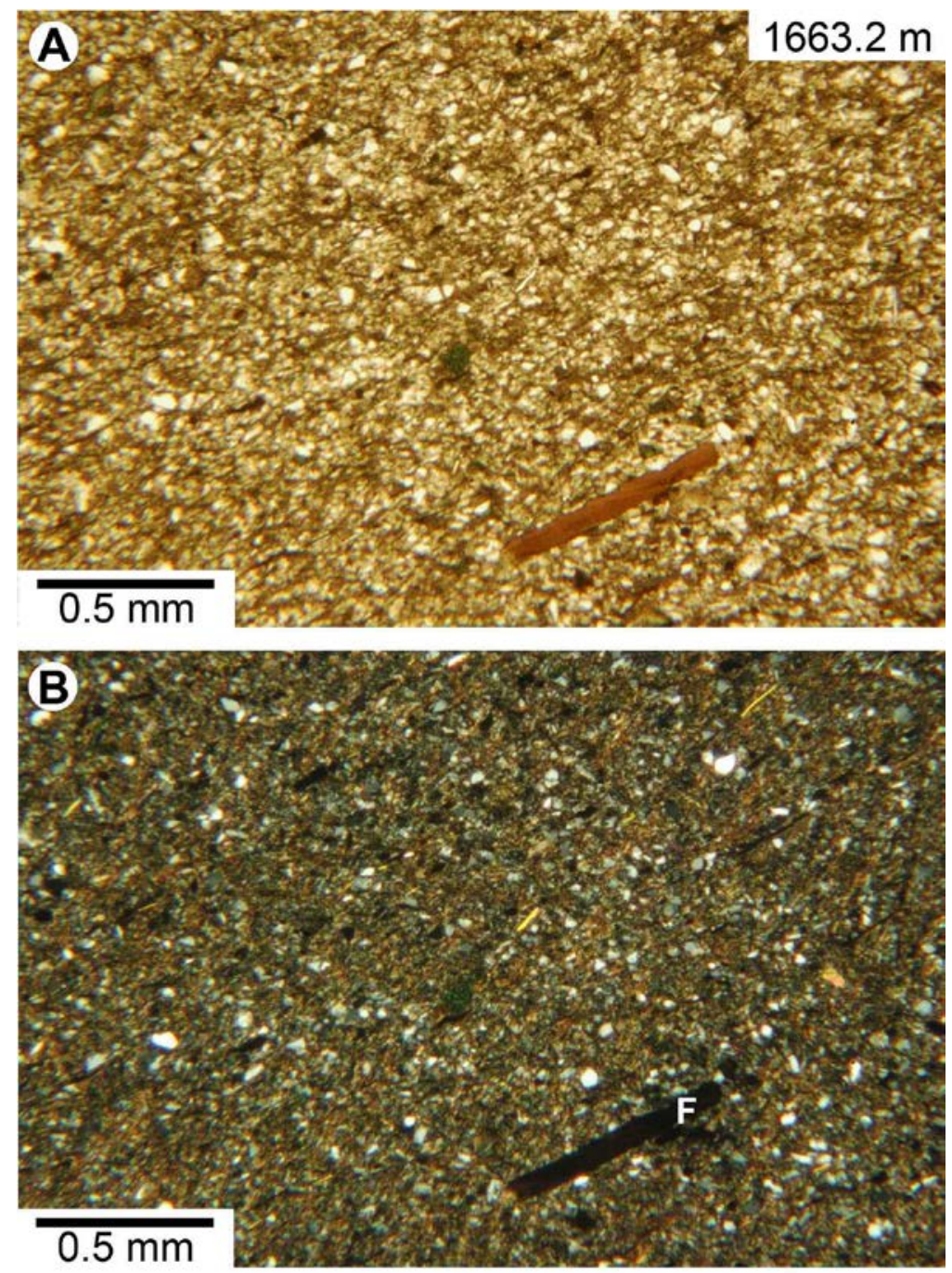

Figure A1. 1 Photomicrographs of Eau Claire Shale cap rock (from a depth of 1,663.2 m). $A$, viewed in planepolarized light: $B$, the same view under crossed polarizers. The fossil, labeled $F$ in photomicrograph $B$, is oriented parallel to bedding in the shale. The rock is fine grained, and the pore spaces are filled with authigenic clays that substantially reduce porosity and permeability. 

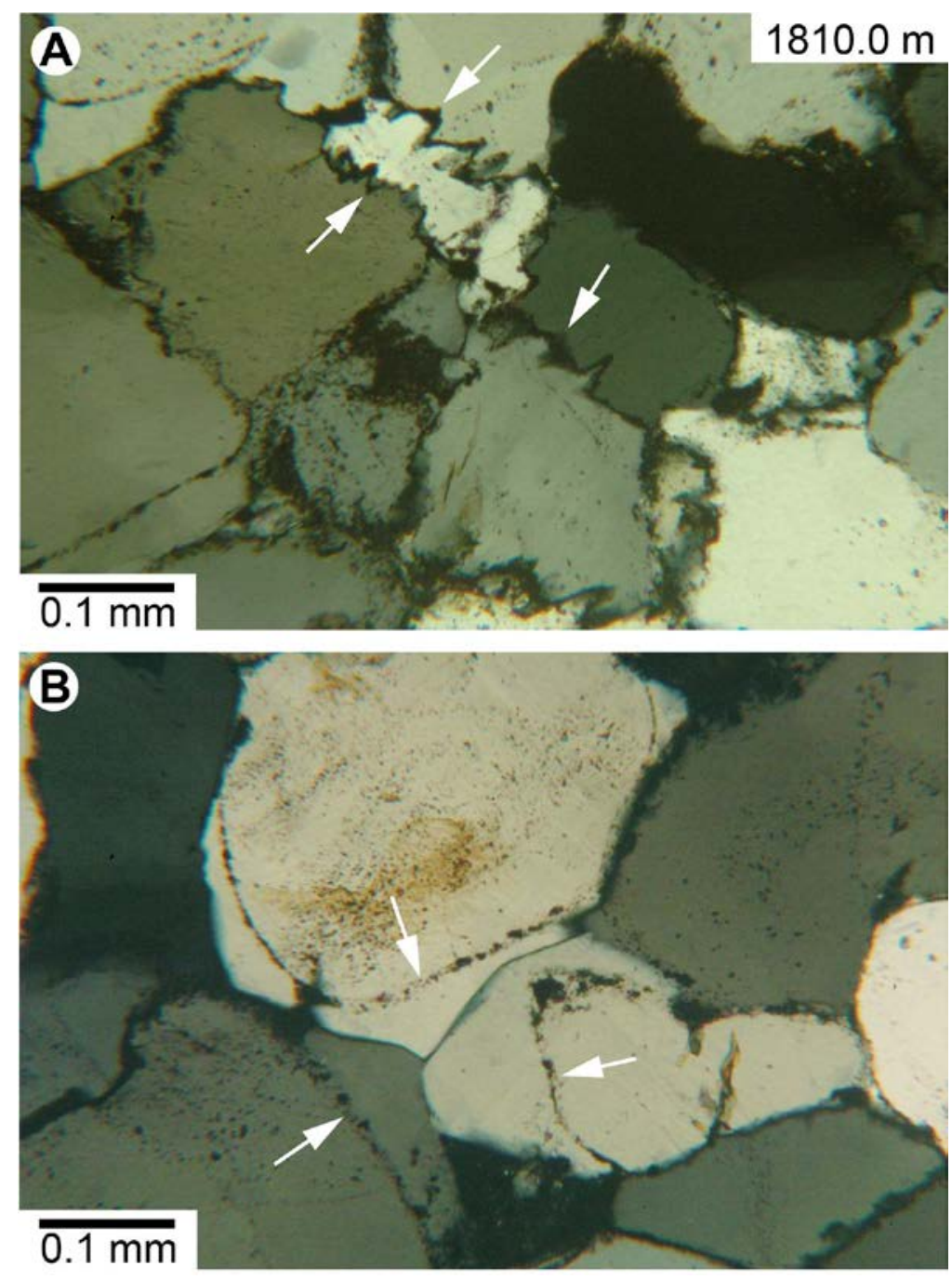

Figure A2. 100 Photomicrographs of Mount Simon Sandstone subunit $D$ (from a depth of $1,810.0 \mathrm{~m}$ ). This sample is a nearly pure quartz sandstone, and it has the lowest porosity and permeability of the tested reservoir rocks. $A$, Sutured grain boundaries, marked by arrows, were produced by dissolution of silica at stressed contacts. Suturing lowers porosity and increases tortuosity of the affected grain boundaries; $B$, Silica overgrowths on adjoining quartz grains that largely fill the pore space. Arrows point to the original grain boundaries, and the quartz in the overgrowths is in optical continuity with the quartz in the clasts. Overgrowths can also be seen at the upper and lower left corners of photomicrograph $A$, along grain boundaries oriented perpendicular to the sutured surfaces. 


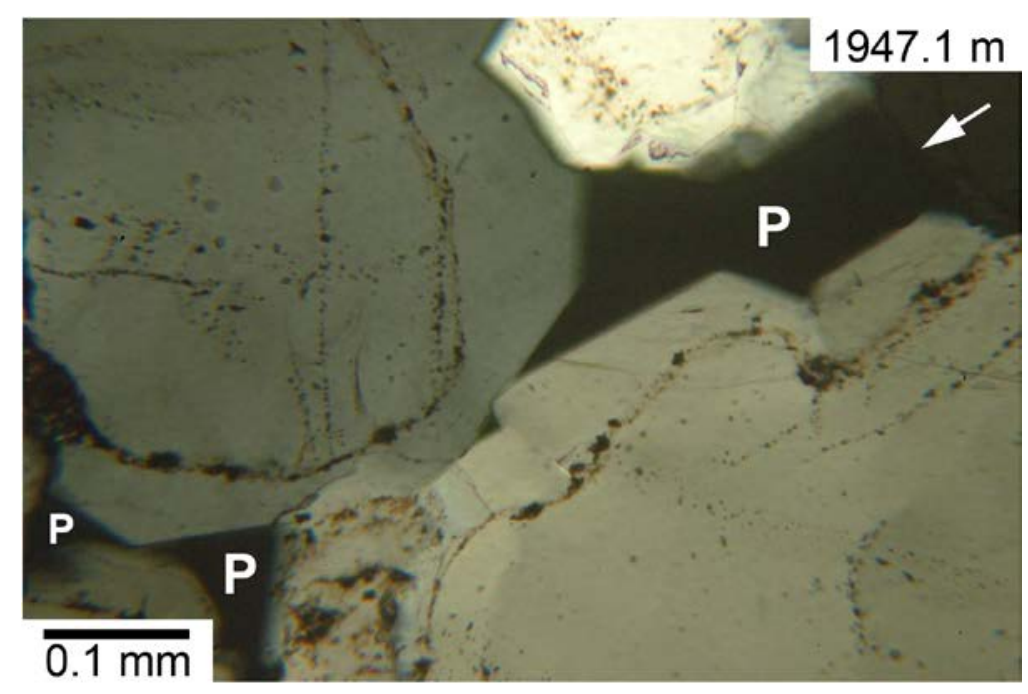

Figure A3. 10 Photomicrograph of Mount Simon Sandstone subunit C (1,947.1 m) viewed with crossed polarizers. This sample contains considerable amounts of feldspar as well as quartz. Overgrowths of $\mathrm{SiO}_{2}$ on quartz clasts are common, but a modest number of partly open pores (labeled $P$ ) remain. As a result the porosity and permeability are somewhat higher than that of the Mount Simon Sandstone D reservoir rock (see fig. A2). The arrow denotes the poorly visible outer edge of a quartz grain at extinction that bounds the large pore at upper right. 

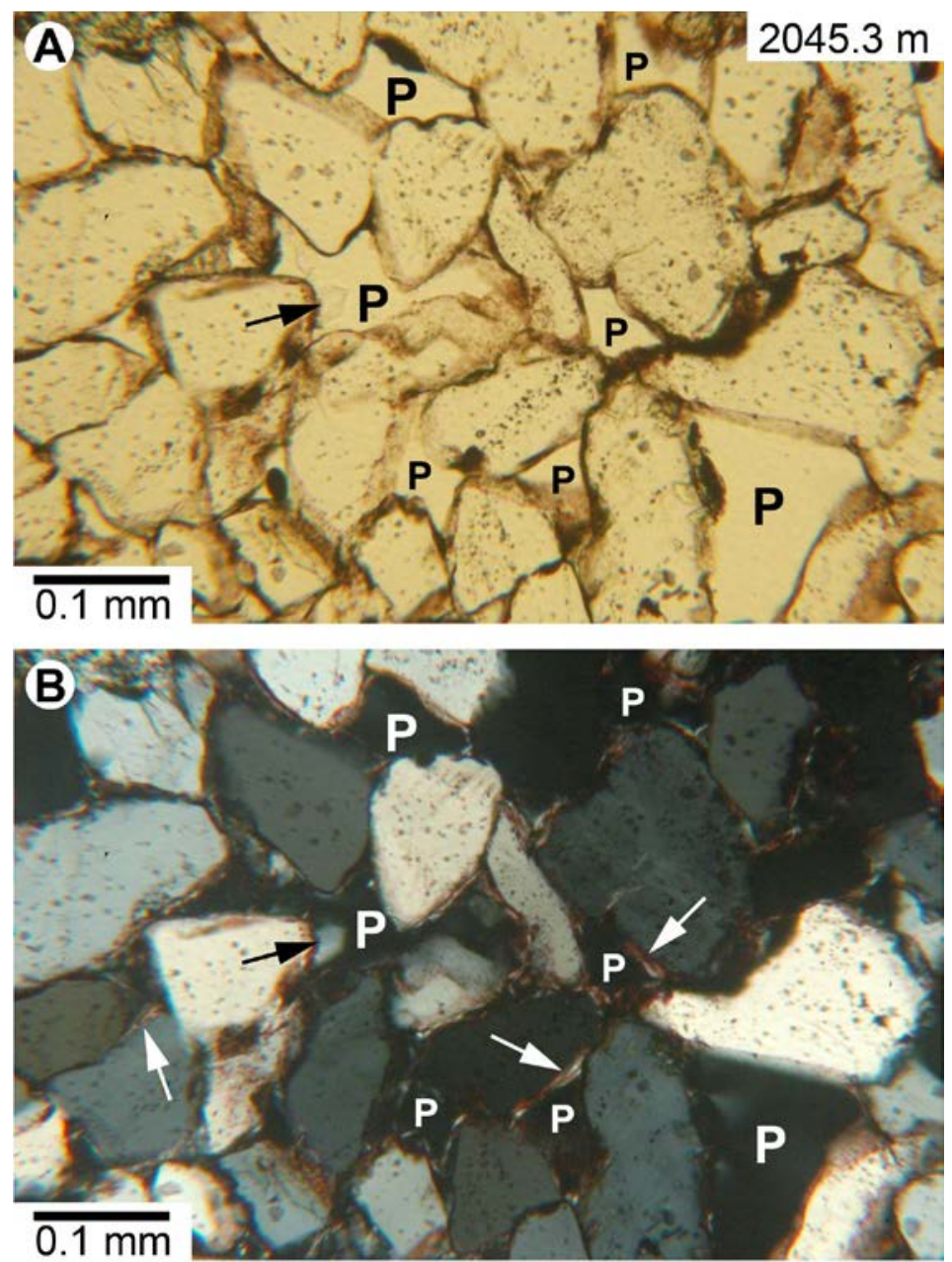

Figure A4. 4 Photomicrographs of Mount Simon Sandstone subunit A upper (2,045.3 m). Relatively well sorted, fine-grained sandstone viewed with $(A)$ plane-polarized light and $(B)$ crossed polarizers. Open pores (labeled $P$ in both photos) are very abundant, and this is the highest porosity sample. Pore walls are typically lined with clays or red-tinged iron oxides; a few examples of the clay coatings are marked by white arrows in photomicrograph $B$. Clays lining pore throats may impede the migration of pore fluids, causing permeability to be somewhat lower than expected based on the porosity. A small quartz crystal with euhedral termination extends partway across one of the pores (black arrow in both photos); the crystal is not in optical continuity with the quartz grain on which it grew. 


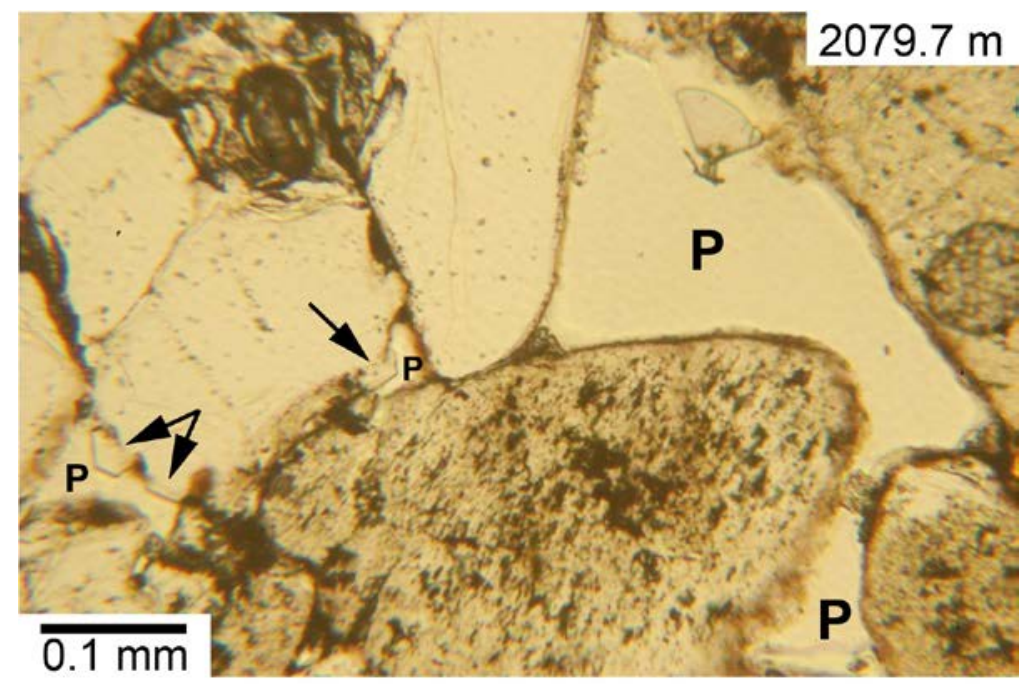

Figure A5. 1 Photomicrograph of Mount Simon Sandstone subunit A upper (from a depth of 2,079.7 $\mathrm{m}$ ) viewed with plane-polarized light. This poorly sorted, arkosic sandstone with few clays has the highest permeability but moderate porosity among the reservoir rocks. A contributing factor to the high permeability is the presence of open pores (labeled P) not lined by clays that might otherwise impede fluid flow at pore throats. The small clay content is concentrated in a few locations. Arrows mark the locations of quartz crystals that grew into two of the smaller pores. 

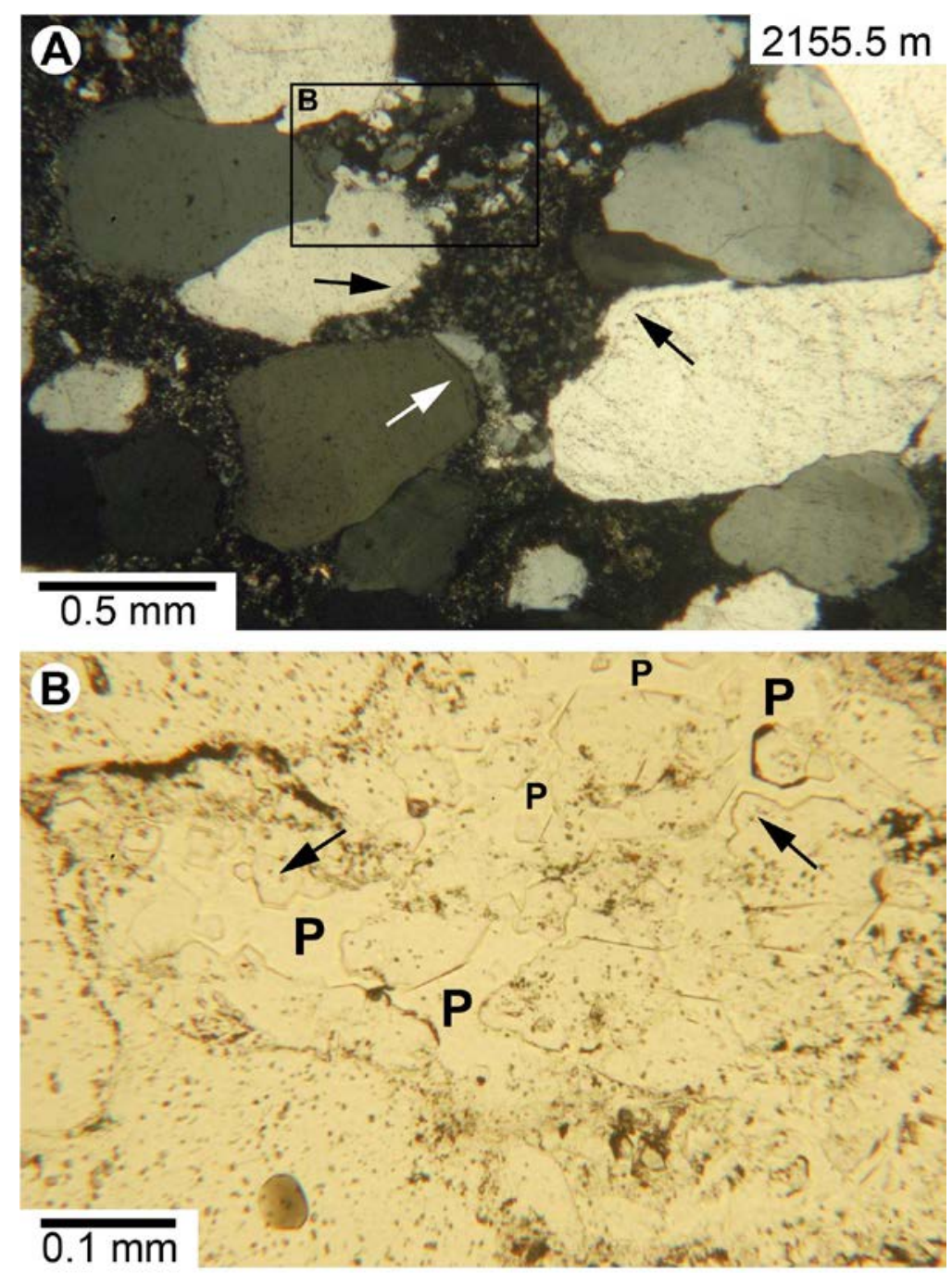

Figure A6. Photomicrographs of pre-Mount Simon sandstone. A, Lower-magnification photomicrograph, taken with crossed polarizers; $B$, Closer view, in plane-polarized light, of the area in photomicrograph $A$ outlined by the box labeled $B$. This sample consists largely of quartz and kaolinite with minor amounts of mica, based on X-ray diffraction analysis. A considerable proportion of the kaolinite occurs in large patches, for example the center of photomicrograph $A$, suggesting the replacement of detrital feldspars by kaolinite, with quartz overgrowths on the adjoining quartz clasts (black and white arrows). Patches of fine-grained quartz and clay minerals, such as the one shown in photomicrograph $B$, may also have replaced detrital grains during diagenesis or low-grade metamorphism. Many of the quartz crystals have euhedral faces (black arrows) and the patches have relatively high secondary porosity $(P)$. However, these high-porosity patches are localized, and the abundance of matrix clays throughout the rock will tend to reduce permeability. 

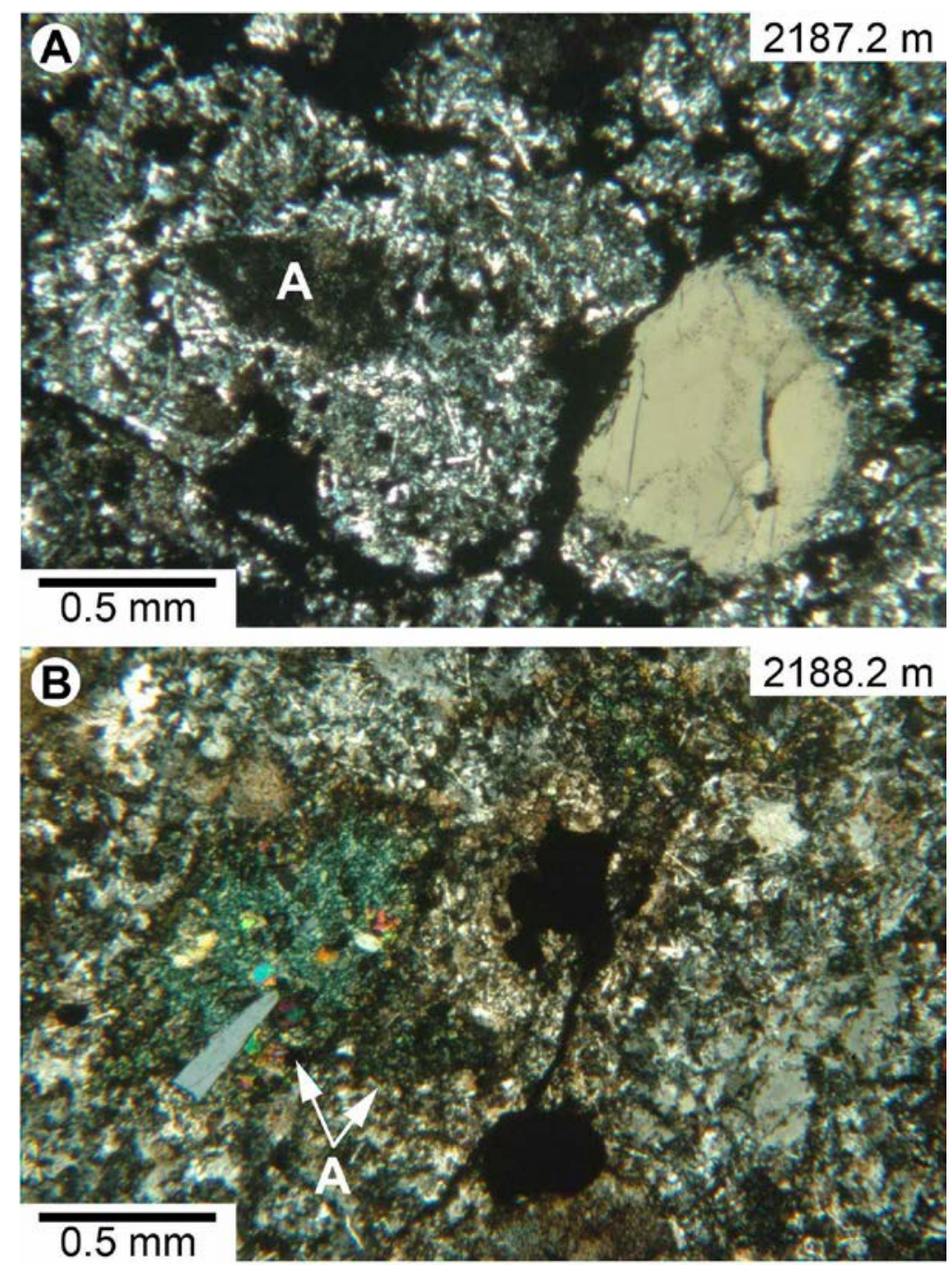

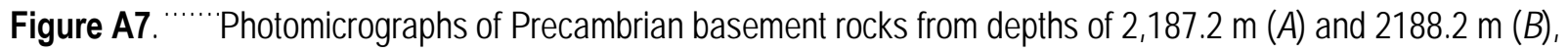
viewed with crossed polarizers. The basement rocks have the lowest porosity and, for the most part, the lowest permeability values measured in this study. Both samples are metavolcanic rocks with a recrystallized quartzofeldspathic groundmass with an interlocking texture. Locations marked $A$ in both photos have the outlines of amphiboles but have been replaced by chlorite-bearing assemblages. The large altered amphibole in photomicrograph $B$ also contains epidote (small, highly birefringent crystals) and apatite (gray rod). Microfractures are filled with chlorite and (or) iron oxides. 


\section{Appendix 2. Anisotropy in Elastic Properties of Shale}

Preferred bedding orientation in shale leads to pronounced anisotropy in elastic properties. Similar to Deng and others (2015), we assume transversely isotropic stress-strain relations represented by equation (5). The 1-2 plane is assumed to be the plane of isotropy (bedding plane) and axis 3 has rotational symmetry (Lekhnitskii, 1963).

$$
\left[\begin{array}{c}
\varepsilon_{11} \\
\varepsilon_{22} \\
\varepsilon_{33} \\
2 \varepsilon_{23} \\
2 \varepsilon_{13} \\
2 \varepsilon_{12}
\end{array}\right]=\left[\begin{array}{cccccc}
\frac{1}{E} & -\frac{v}{E} & -\frac{v^{\prime}}{E^{\prime}} & 0 & 0 & 0 \\
& \frac{1}{E} & -\frac{v^{\prime}}{E^{\prime}} & 0 & 0 & 0 \\
& & \frac{1}{E^{\prime}} & 0 & 0 & 0 \\
& & \frac{1}{G^{\prime}} & 0 & 0 \\
& & & & \frac{1}{G^{\prime}} & 0 \\
\sigma_{33} \\
\sigma_{23} \\
\sigma_{13} \\
\sigma_{12}
\end{array}\right]
$$

There are 5 independent elastic moduli in the compliance matrix. $E$ and $v$ are Young's modulus and Poisson's ratio for an applied normal stress in the plane of isotropy. $E^{\prime}$ and $v^{\prime}$ are Young's modulus and Poisson's ratio for an applied normal stress perpendicular to the plane of isotropy. $G$ is the shear modulus for shear stress applied in the plane of transverse isotropy and $G^{\prime}$ is the shear modulus corresponding to shear stress applied in planes that include the axis of rotational symmetry.

Given the rotational symmetry for deformation measurements performed in the triaxial test geometry, shear stress is not applied directly to the sample faces and $G^{\prime}$ cannot be measured. In principal, $G$ can be calculated from determinations of $E$ and $v$ as indicated in equation (5). We performed tests on Eau Claire Shale samples that were cut in two orientations. In the first test, the sample was mounted with the bedding plane perpendicular to the loading frame axis. In this case, application of an axial stress corresponds to varying $\sigma_{33}$ in equation (5): $\sigma_{\mathrm{ax}}=\sigma_{33}$. Axial and transverse strain gauges can then be identified with strain components according to: $\varepsilon_{\mathrm{ax}}=\varepsilon_{33}$ and $\varepsilon_{\mathrm{tr}}=\varepsilon_{11}=\varepsilon_{22}$. For this test geometry, equation (1) leads to: $E^{\prime}=\sigma_{\mathrm{ax}} / \varepsilon_{\mathrm{ax}}$ and $v^{\prime}=-\varepsilon_{\mathrm{tr}} / \varepsilon_{\mathrm{ax}}$.

In the second test, the sample was oriented with the bedding plane parallel to the test frame axis and strain gauges were applied to the sample face that was perpendicular to bedding. For this geometry, we identify $\sigma_{\mathrm{ax}}=\sigma_{11}, \varepsilon_{\mathrm{ax}}=\varepsilon_{11}$ and $\varepsilon_{\mathrm{tr}}=\varepsilon_{33}$. Solving equation (5) gives: $E=\sigma_{\mathrm{ax}} / \varepsilon_{\mathrm{ax}}$ and $\nu^{\prime}=-\left(\varepsilon_{\mathrm{tr}} / \varepsilon_{\mathrm{ax}}\right)\left(E^{\prime} / E\right)$. Note that this placement of strain gauges provides a second determination of $v^{\prime}$. We did not perform the additional test in which the transverse strain gauge was attached to the sample face parallel to bedding. This test would provide a measure of $v$ (and indirectly, $G$ ). Thus, we provide measurements of $E^{\prime}, E$ and $v^{\prime}$. 
ISSN 2331-1258 (online) https://doi.org/10.3133/ofr20171094 